\title{
Measuring Ideologically-Based Responses
}

\author{
Hanan A. Ebaid ${ }^{1}$ \\ ${ }^{1}$ Faculty of Arts, Sohag University, Sohag, Egypt \\ Correspondence: Hanan A. Ebaid, Faculty of Arts, Sohag University, Sohag, Egypt.
}

Received: September 24, 2018 Accepted: October 18, 2018 Online Published: November 28, 2018

doi:10.5539/ells.v8n4p46 URL: https://doi.org/10.5539/ells.v8n4p46

\begin{abstract}
The current paper attempts to propose a device by which ideologically based responses can be measured in the interpersonal discourse of ideology. As a result of some drastic political changes, the Egyptian society has witnessed during the last five years a wave of conflicting ideologies, each of which is endorsed by some people and rejected by others. The different types of social media such as Facebook and Twitter are global and influential channels of the communication of diverse ideologies. A Facebook account of a supposedly Egyptian Jewish woman was specially created for collecting the data to be analysed in this paper. The paper is a qualitative research whose data is collected through an interaction between a Facebook account owner and some other users. The data is categorized into three groups each of which represents a certain area in a spectrum of ideologically based responses. One of the main findings reached through data analysis is that ideological responses can be measured and that there are mainly three types of responses in interpersonal ideological discourse, namely positive, passive and negative. It also concludes that each type of responses displays some distinctive features. This spectrum helps measure and interprets different types of responses to one's ideology.
\end{abstract}

Keywords: discourse semantics, ideological spectrum, Facebook, interpersonal discourse, polarization

\section{Introduction}

Language is the carrier and transmitter of our thoughts, beliefs, feelings and ideas. It reflects the way we conceptualise the world around us with its diverse and complicated relations and interactions. Human beings are members of social groups each of which has its identity, values, norms and interests; these aspects are closely and strongly connected with ideology. Ideologies are believed to be, as Van Dijk 1995a puts it "the axiomatic oasis of the socially shared belief systems of groups" (p. 244). The members of a certain social or political group, for instance, endorse an ideology that governs to a great extent their values and practices that would distinguish them from other groups. Van Dijk (2013) notes that "Generally — though not always - such a self-image of the ideological in-group is positive, whereas that of out-groups is negative. Hence the typical polarized structure of ideologies as organized representations as Us versus Them" (p. 178).

The main objective of this study is to show that ideologically based responses in interpersonal discourse can be measured in terms of a three areas spectrum. This, in turn, facilitates interpreting and classifying such responses. The question of whether responding positively or negatively to one's ideology may occur with the lack of actual personal acquaintance arises in this respect. This paper focuses on some discourse semantics aspects as outlined by Van Dijk, which help explain how responses to one's ideology are measured. Polarization represents another issue of interest, but it is manifested in this paper as a reaction towards an individual's interpersonal communication. An important question that arises in this respect is why a person is polarized as either being for or against a specific group even when he/she does not act in a way that would convey such an impression. The answer to this question is provided later.

Facebook is the medium through which the data to be analysed is collected. It is one of the most widely accessible electronic tools that people use to publish, share and exchange information, ideas and, most importantly for the purposes of this paper, ideology. The selection of Facebook is attributed to the fact that it is one of the easiest ways of establishing relationships without the need of face to face interaction. In this virtual community, a person may have more than one account with unreal identity and names. However, it remains the most popular social network worldwide as Facebook had 2.2 billion monthly active users for the fourth quarter of 2017 as reported by (The statistics portal, 2018).

Raheel Zaki, supposedly an Egyptian Jewish woman, interacts with others through her Facebook account to 
scrutinize how far others react to her ideological stance of citizenship as belonging to land, not religion and whether she is accepted and welcome as an Egyptian national or not. The following sections handle some relevant threads, method of research, results and discussion and finally the conclusion.

\section{Some Relevant Threads}

According to Kasaian \& Tehrani (2013) ideology "refers to the ways individuals or groups view the world. It is a set of ideas that constitute one's goals, expectations, and actions" (p. 24). Those ideas are expressed and spelled out through the use of language to be understood and reacted to whether in a positive or a negative manner. Van Dijk (2001) states that ideologies "form the basis of the social representations and practices of group members, including their discourse, which at the same time serves as the means of ideological production, reproduction and challenge" (p. 12).

There is a strong bond between language and ideology, the former mirrors the latter in an explicit manner which is reacted to by others whether positively or negatively. Simpson (1993) notes that language must necessarily echo ideology because it is a form of social behavior which regularly operates in discourse contexts with abundant exchange of ideology. Thus, Raheel, as a member of the Egyptian society, wishes to share her ideology of citizenship and co-existence with others.

\subsection{Group Membership}

Human beings are born with the natural inclination to be social beings who live and interact in groups. Belonging to a group basically necessitates the commitment to what Tuomela (2007) calls "the group's "ethos - its constitutive goals, values, standards, beliefs, and practices" (p. 14). This commitment is presumably a feature of any group type whether it is political, social or religious. In this case, a group member undertakes many forms of actions and practices in accordance with the goals of the group. Some groups such as ISIS are thought to hold extremist and brutal beliefs and deeds which are executed by its members. Thinking and acting as a group member is not at odds with being a private person who has his own practices such as work, exercise and hobbies.

Kristiansen (2001) claims that social groups enable their members to identify themselves in social terms. Kristiansen further notes that this identification is both relational and comparative. Consequently, an individual is judged as being similar to or different from, and as better or worse than members of other groups. This pertains closely to the concept of social identity which refers to one's self-image that is mainly shaped by his/her knowledge of belonging to a social group. In the current paper, Raheel believes that she is a patriot who wholeheartedly wants to be accepted and treated as an in-group, not an out-group member.

It has been remarkably noted that the Egyptian society has witnessed dramatic changes since the outbreak of the 2011 revolution. One of the main consequences of these events is the categorization of Egyptians into different groups like Muslim Brotherhood, Salafis, secularism, and the sofa party; an entirely new group that emerged within this period referring mainly to those who refrain from actively taking part in political incidents such as parliamentary or presidential elections.

Each group is identified by the use of certain expressions reflecting its ideological conception of the overall system of the state. Thus, Muslim Brotherhood and Salafis speak about a religious state which executes the Islamic sharia (the holy laws of Islam that cover all aspects of a Muslim's life), while secularists call for a non-religious state. Other groups, belonging to diverse ideologies, use the term "the rule of 'al 'askar" to exhibit their opposition to the intervention of the supreme council of the armed forces in political life.

What needs to be asserted in this respect is that lexical choice mirrors its user's ideology according to which he/she is identified, judged and even reacted to. Usually, members of a certain group tend to use some fixed expressions that distinguish them from other groups.

In the case of the current study, Raheel repeatedly uses what she holds to be a fixed expression or what would be called collocation stating that citizenship is belonging to land not religion, which is deliberately manipulated by her in order to achieve many goals; first, to assert her wish to be socially integrated within the Egyptian society as a citizen who should have all his/her rights. Second, to examine how others would react to her thoughts and beliefs, and to be consequently able to discover their own ideology. Third, to ascertain that belonging to homeland is the main criterion that determines her nationality and that other aspects like religion, and gender should be excluded. The subsequent section discusses the method of research and the theoretical framework upon which data analysis depends. 


\section{Method}

The current study is a qualitative descriptive research that depends on collecting and analysing qualitative data. The data to be analysed is collected from Raheel's interactions with some of her Facebook friends. This Facebook account is specially created by the researcher for this study. Judaism as Raheel's religion has been deliberately chosen as Egyptians are generally, due to the Arab-Israeli conflict, prejudiced against Jews and Israelis.

The samples represent computer-mediated discourse. Androutsopoulos \& Beißwenger (2008) state that "Computer-mediated discourse (CMD) encompasses all kinds of interpersonal communication carried out on the Internet" (p. 1). In the present study, data collection depends entirely on Facebook interaction between Raheel and other users. The main reason behind the choice of Facebook to be the medium through which Raheel interacts with others is that face- to- face communication is not necessary. This facilitates the researcher's task through a fake account to express Raheel's ideology and to assess that of others. The data is divided into three groups each of which focuses on a specific ideologically based response type as will be shown later.

Due to some ethical issues such as anonymity and privacy protection, the true identity of the participants with whom Raheel interacts is concealed. Therefore, there is a non-to-be published appendix containing the screen shots of the analysed data which could be examined only by the panel of this paper. The data is translated into English and is integrated within the text of the paper; initials of the participants' names substitute their full names.

The theoretical framework of this study is based on some of Van Dijk's concepts of ideology and discourse (1995a, 1995b, 2001, 2013). For him, text and talk are the means by which ideologies are expressed, exchanged and judged. Van Dijk (1995b) regards discourse as a form of social representations and practices performed by group members. Van Dijk (1995a) believes that ideologies are socio-cognitive in nature and explains this by stating that "besides their social function of sustaining the interests of groups, ideologies have the cognitive function of organizing the social representations (altitudes, knowledge) of the group, and thus indirectly monitor the group-related social practices, and hence also the text and talk of members" (p. 248). This strongly indicates that members of a certain group share the same or similar mental representations that are echoed by their use of language that simultaneously identifies them and distinguishes them from other groups.

Mental models and context models are of prime importance for the current study. Van Dijk (2001) characterizes mental models as those that "constitute the personal, episodic memory of individual people. They are shaped by an individual's experiences of the events and situations in which he/she is involved" (p. 16). It should be borne in mind that mental models are highly subjective as they encompass personal opinions. However, these mental models may in many cases be instigated by social attitudes shared by members of a specific ideological group.

On the other hand, Van Dijk (2001) identifies context models, or simply models as "subjective, mental representations of the communicative event and the current social situation as it constrains current discourse" (p. 17). Thus, a context model refers to a communicative event involving some participants who exchange their ideologies. This exchange represents personal opinions which are largely influenced by the attitudes of a certain group. He (2013) further notes that "the context models also consist of a spatiotemporal setting, a representation of the current identity and role of the participants as well as the relations between them, the current social action and its goals, as well as the knowledge and ideology of the participants" (p. 181). Facebook represents the spatiotemporal setting in this study in which Raheel interacts with other participants embracing different and in some cases conflicting ideologies.

Turning to the semantic aspects of ideological discourse, we refer to Van Dijk's concept of ideological discourse semantics which comprises underlying ideological meanings and their expression through various forms. Some of these forms as discussed in Van Dijk (2013) are:

Actor descriptions. Generally speaking, an individual may be identified in a number of ways; by his/her own name, by a certain title or by being a member in a certain group. In some cases, actor descriptions are meant to be an ideologically based identification of people who may be described and referred to by negative attributes if they are regarded as out-group members.

Topics. There is a distinction between local semantics and global semantics or topics. The former relates to the meanings of words, clauses and sentences in a certain discourse, while the latter pertains to the overall global meanings of the whole discourse, namely topics.

Propositions. A proposition mainly consists of a predicate and some arguments. There may be negative predicates that convey negative and undesirable significance. In the following section, data analysis is done in 
terms of the above mentioned theoretical elements in order to measure and classify responses to one's ideology. Every type of responses is placed at a specific area of the proposed spectrum of ideological responses. Figure 1 represents the spectrum

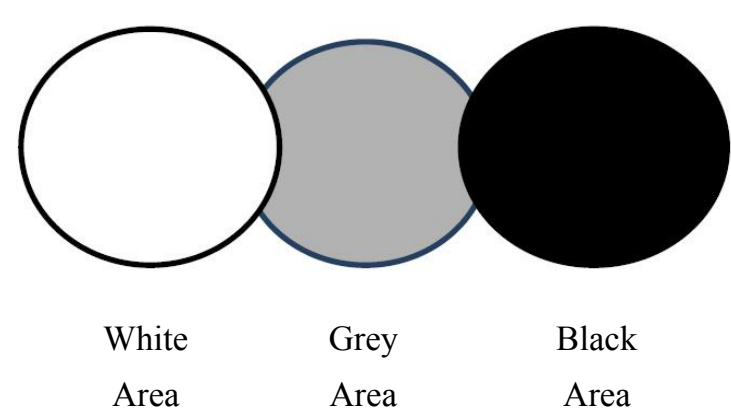

Figure 1. Spectrum of ideological responses

This spectrum and its picture are proposed by the researcher to be a tool by which different responses are categorized and measured. The white area corresponds to positive, agreeable and supporting responses that share the same or at least a similar ideological background with Raheel. This is represented by the lexical choice of respondents. The grey area is characterized by the complete absence of language use and it is difficult to determine the addressee's attitude towards Raheel's ideology. This passive unclear situation justifies the presence of the grey area. The black area includes negative, aggressive and incompatible responses with Raheel's concept of citizenship and co-existence. This is echoed by the use of some offensive expressions as will be shown in the following section.

\section{Results and Discussion}

The analysed data is classified into three groups each of which measures a specific type of ideologically based responses to Raheel's posts and occupies an area on a proposed ideological spectrum. It should be noted that the context models in the three groups comprise Raheel and her Facebook friends with their mental models representing their ideologies. The distinctive nature of every area is primarily determined by her Facebook friends' responses. These groups are presented and discussed below.

\subsection{Group A}

\section{Positive responses}

Ideologically-based responses in this group are positive in the sense that they agree on and support Raheel's ideas of co-existence and tolerance. The context models of the Facebook posts in this group highlight the harmonious and compatible ideological stance between Raheel and her Facebook friends. It is clear that Raheel and other participants share the same conception of citizenship as being belonging to land, not religion. It strongly seems that their mental models, based on personal experiences, are to a great extent similar. Thus, for example, Raheel in 1 complains about the absence of tolerance among people and A.E. starts his response saying hada șạịh, this is true. This phrase shows his consent to Raheel's preceding statements.

The six extracts in this group are cited, then participants' responses are analysed in terms of Van Dijk's discourse semantics aspects of actor description, topics and propositions. Finally, every response type in the three groups is placed in its proper area on the proposed ideological spectrum.

1. raḥil zaki. 'aškurkum 'ala 'iḍāfa 'ala șafḥit 'almu' arih 'alkabīr 'in 'alif. 'ana mișriyat -lğinsiya yahudiyat -lğinsiya ( a misprint) laysa li wațan gir mașr. fi ra'yi 'almuwāțana 'aṛ̣ w 'iḥlāṣ liturāb 'arḍ -lwațan wa laysat dīn. ma 'ulāḥizun 'al'ān gìīāb 'attasāmuḥ wa -tta āyuš 'illi kānu mawğudīn zamān w dah ši' biyu' limni.

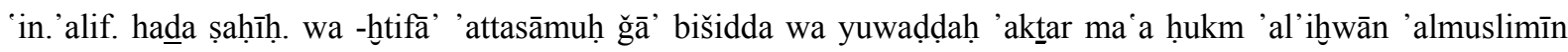
'alladīn la ya rifūn -lwațan 'alladi yaḍum kul man ya ĩš 'alayh bișarf innaẓar 'an il'aṣl wa ddīn wa -lmadhab. wa hadihi -lfitna bada' at ma 'a 'assadāt 'indma 'afrağ 'an 'al' ihwwān 'almuslimīn min 'assuğūn 'ām 1972 wa samaḥ lahum bi-lnašăt 'al alani fatagialgalū fi kul -ilğam iyāt wa -lğami āt wa -nniqabāt ḥata ğā'athum 'alfurșa ba d 2011 bitašğî' min 'amrīka lilmusā'ada fi tafkīk 'alwațan 'alwāḥid 'ila 'iddat 'awțān. wa lākin la yanbag̉i 'an nay'as fasawf tastarid mașr 'afiyatha bi fạ̣l yaqaẓat 'almustanīrīn 'alharișūn 'ala waḥdat 'alwațan wa 'isti ādat quwatih 
1. Raheel, "Thank you for adding me to the page of the eminent historian A.E, I am Egyptian and a Jewish national (a misprint, it should have been embracing Judaism). The only homeland I know is Egypt. I believe that citizenship is loyal belongingness to land not religion. Now, I notice the lack of tolerance and coexistence that used to be in the Egyptian society a long time ago. This hurts me."

A.E. (The historian), "It is true. The lack of tolerance became more obvious during the rule of Muslim Brotherhood who don't know the homeland which embraces everyone living in it regardless of origin, religion or doctrine. This sectarian strife started by Al-Sadat in 1972 when he released members of Muslim Brotherhood and allowed them to work publicly. Therefore, they penetrated all associations, universities and guilds, till they grasped the opportunity encouraged by the U.S to disunite the country into several countries in 2011 . We shouldn't despair, Egypt will recover as a result of the attentiveness of the enlightened who care for the unity of homeland and regaining its strength."

2. mīm. 'alif. baškurik '-l'iḍāfa šukran ğazīlan' ana 'ārif 'innik ma ti rafin̄̄š wa -na kamān bas 'ağabni fikrit 'ittasāmuh 'illi bit' abbari bīha fi ta liqātik. šukran

2. M.A., "Thank you very much for adding me. We don't know each other, but I like the way you express tolerance and coexistence in your comments. Thanks."

3. ma ț̣anafn İs

rahịl zaki. ma 'aqșidu 'alla yakūn 'ittaṣnīf madḩal litafkīr 'unșuri

mīm. 'alif. qīmat 'al'insān la tatag̉ayyar bisabab lun bašritu, dīnu aw šaklu sayaẓal 'insān lahu ḥuqūq 'al'insāniya wa 'adamiyatu wa fițratu fi ḥaq -lḥayā. 'inna -llāh la yanẓur 'ila 'aškālikum wașuwarikum wa lākin yanẓur 'ila ma fi qulūbikum (Note 1). la liltașnîf wa -l'unșuriya wa na am lilmuwāțana wa -tta āyuš 'ala 'asās 'ahlāqi wa lays dīni w ymkin da waḍḍahtu liḥậritik min qabl

'alif. lām. la lil 'unșuriya wa na am lil' iḥtilāf lākin la māni' min fahm 'alhalfiya allati taẓhar fi 'arā' wa 'ihntiyarāt kul šahș.

3. Raheel, "Don’t classify me."

Raheel, "What I mean is that classifying people shouldn't lead to racism."

M.A., "Man's value doesn't change due to one's colour, physique or religion. One will be a human being with the right to live. God doesn't look at your figure or body but at what's in your heart ${ }^{1}$. No to classifying and racism and Yes to citizenship and coexistence on moral not religious grounds. I explained this to you before."

Raheel, "As long as there are open-minded and wise persons, things will be ok." (Please delete this line)

A.L., "No to racism, and Yes to difference. There is nothing wrong about understanding the background of one's opinions and choices."

4. șậ. hạâ'. 'almuwāțana ya 'uhti 'arḍ wa dīn la' an 'al'adyān kullaha la tahuḍ 'ala 'attamyīz bayn -nnās kama 'an -ddīn yağ'al al'insān yahââ min 'azẓulm wa -ttamyīz.

rahīl zaki. ma 'aqșidu ya sayidi huwa hal yağib mu amalati kamuwāṭina darağa talta limuğarrad 'inni yahūdiya? birrag̉m min 'inni la 'aqil 'ihlāṣ 'an 'ay muwāțin 'āhnar.

șậ. hậ'. bitt'akīd la la'an 'al'islām ḥarram dalik muṭlaqan wa man lam yu'min bilyahūdiya falaysa musliman ladayna 'almuwātana la ta rif tamyīzan la 'ala 'asās dīn aw nū' aw 'intimā' siyāsi aw fikri wa la bayn ġani wa faqīr wa la bayn wazīr wa hafî̀ wa la bayn ra'īs wa mar' ūs, 'alğamī' mutasāwūn 'amām 'alqānūn wa fi 'alḥuqūq wa -lwağibāt

rạị̂l zaki. da kān qașdi

4. S.H., "Sister, citizenship involves land and religion because all religions are against discrimination. A religion makes man fear injustice and discrimination."

Raheel, "Sir, in spite of the fact that I am not less loyal than any other citizen, do I have to be treated like a third degree citizen just for being Jewish?. This is what I mean by saying that citizenship is land not religion."

S.H., "Of course not. Islam has prohibited this totally. Those who do not believe that Judaism is a religion are not Muslims. Citizenship does not classify people on any grounds like religion, gender, political or ideological interests, and wealth and poverty. All are equal before the law regarding rights, duties and freedom."

Raheel, "This is what I mean."

5. raḥil zaki. 'ila 'adminz 'așșafḥa taḥiyya țayyiba wa ba 'd 'ana mașriyat -lğinsiya yahudiyat 'addiy āna. la 'a rif 
wațan li siwa mașr. fi ra'yi 'almuwāṭana 'arḍ w 'ihlāṣ lil'arḍ wa laysat dīn. min munțalaq hụbbi lilwațan wa hirṣi 'ala mașlaḥtu kunt 'atamana 'an takūn hatihi 'așṣafḥa nāfịda liltawāṣul ma a -lmuwāṭinīn. fayastațī' man 'andu šakwa bimustanadāt tuțbit ḥaqqu 'an yuqadimha wa yatawalla 'al'adminz 'arḍaha ala -lmuh̆tașīn limuhāwalit ḥallaha la 'an takūn 'aș̣afḥa muğarrad 'arḍ likalimāt ra'īs 'alwzarā' huna wa hunāk. šukran wa 'arğu 'adam 'ihmāl risalti

'așșaf̣̣a 'arrasmiya lira'îs 'alwzarā' 'almuhandis ibrāhīm mị̣lib. ḥaḍritik 'ahlan wa sahlan bikī wa law fi 'ay muškila 'and ḥaḍritik ya rit tatawaṣli ma'āna w ị̣na niwașșal 'ilmuškila 'ila 'āli ra'̄̄s mağlis 'alwzarā' 'almuhandis ibrāhīm mị̣lib.

rạịl zaki. šukran lidu'kum. 'ana ma kanš 'așdi muškila hāșa. 'așdi law 'amkan tiktibu 'așșafḥa 'in law fi had 'andu muškila w m ā ma yițbit ḥaqqu y'dar yb atlukum risāla biḥit tirfa 'ūha lilmas' ūl 'almuhtaș 'ašān yihịillaha

5. Raheel, "Hello, to the admins of the page. I am Egyptian and embrace Judaism. I know no homeland other than Egypt. In my opinion, citizenship is loyal belongingness to land not religion. Out of my love and concern with the interest of my homeland, I wish the page would be a means of communicating with citizens. Thus, if someone has a complaint supported by evidence proving his right, he can submit it to the admins who, in turn, send it to those in charge as an attempt to solve it. I wish the page wouldn't just post the prime minister's speeches here and there. Thank you. Don't ignore my message, please."

The official page of the prime minister, "Welcome. Please don't hesitate to contact us if you have any problem. We will send it to the prime minister engineer Ibrahim Mihlib."

Raheel, "Thank you for your courtesy. I don't mean a personal problem. I wonder if you tell people that you are ready to contact those in charge to solve problems of citizens who send them to you."

6. fi muğtama 'na 'ittașnīf wașal liḥad 'innās 'illi mātit w illi lisa hatmūt, 'innās bada'it tis'al huwa 'illi māt da (---) wa la (---) wa la mumkin yukūn (---)w 'ala ḥasab 'ittașnīf da yiqarrar hayiz' al 'ala 'illi māt da wa la la'...?

mīm. 'alif. li 'ilmawḍ̄̄ da fāri' mi āki kida 'ay makān fi 'ilfikr da w fīh 'aksu matḥuṭiš nafsik fi dayrit 'in kul ši' taṣnīf w trakizi mi ā w ba din 'illi yṣanaf huwa ḥur huwa galat lākin miš hatuḥ̣uri -nnās w timši warāhum w t'ulilhum kida galaṭ miš hayinfa' ta' abti nafsik

6. A post shared by Raheel. It says, "In our society, even people who died or will die are classified. People start asking whether the dead person is (....) and (....) or could be (...). People decide whether to feel sorry for a dead person or not according to the way he is classified."

M.A., "Why are so concerned with this matter? You can find those who are with or against this way of thinking everywhere. Don't get caught up in classifying everything. After all, the one who classifies people is mistaken. You can't keep following and telling people that this is wrong. This is exhausting."

Concerning discourse semantics aspects, it should be emphasized that Raheel Zaki as an actor description is deliberately chosen to attract the attention of other Facebook users because this name is well known in the Arab world as that of a Jewish female. The main purpose behind this is to measure and categorisethe different responses of others to her identity. It is quite evident that Raheel is welcome by others in this group and is treated as an in-group member.

Topics. In these samples, citizenship and Raheel's wish that all Egyptian citizens are to be treated equally represent the main topics or more specifically global semantics. Local semantics or the meanings of clauses and sentences mainly centre around the call for the spread of coexistence and tolerance as the words of A.E and M.A in 1 and 2 imply that they accept and welcome Raheel as an in-group member. Being a historian, A.E presents a brief academic account to explain the reason for the absence of tolerance from the Egyptian society and he puts the blame on the former president Al-Sadat who enabled members of Muslim Brotherhood to penetrate all Egyptian associations. In 2, M.A willingly sends her a friend request. In 3 and 6 , she strongly rejects the discrimination and misjudgments on others. In 3, Her Facebook friends M.A and A.L support her and M.A in 6, advises her not to dwell on this matter. In 4, S.H asserts that all citizens regardless of their religious or social backgrounds should be treated equally. In 5 , the admins of the official page of the then prime minister cordially respond to her message and offer to help her if she faces any problems.

Concerning propositions, the predicates and arguments in this group focus on how people conceptulaize the nature of coexistence and how others are treated as either in-group or out-group members. In 1, negative predicates mainly indicate the rejection of some concepts as in laysa li wațan gir mașr, for me, there is no homeland other than Egypt; laysat dīn, is not religion; la ya rifūn -lwațan 'alladi yaḍum kul man ya ĩš 'alayh, they don't know the homeland which embraces everyone living in itand la yanbagi 'an nay'as, we shouldn't 
despair. In the first two instances, Raheel rejects the idea of identifying citizenship in terms of religious beliefs and that is why she asserts that there is no homeland for her but Egypt. In the third case, the negative predicate refers to Muslim Brothers' exclusion of some groups that are ideologically incompatible with them. The fourth example is advice not to despair at the then unstable political circumstances.

In 2, baškurik '-l'ị̂āfa šukran ğazīlan, thank you very much for adding; 'ağabni fikrit 'ittasāmuh 'illi bit' abbari bīha fi ta liqātik, I like the way you express tolerance and coexistence in your comments. These predicates echo having shared and similar ideas of tolerance and co-existence with Raheel.

In 3, ma ț̣anafnī̌s, do not classify me; qīmat 'al'insān la tatag̉ayyar bisabab lun bašritu dīnu aw šaklu, man's value doesn't change due to one's colour, religion or physique. 'inna -llāh la yanzur 'ila 'aškālikum wa șuwarikum, God doesn't look at your figure or body; la liltașnīf wa -l'unșuriya wa na am lilmuwāțana wa -tta 'āyuš, no to classifying and racism and yes to citizenship and coexistence; la lil 'unșuriya wa na am lil' ihtilāâf, no to racism, and yes to difference. The use of negative predicates by two of Raheel's friends as a response to her do not classify me post emphasize their refusal of unfair classifying of people.

In 4, Raheel's friend ascertains his concept that all citizens are equal through the use of negative structures that refer to principles that discriminate people as in 'almuwātana la ta' rif tamyīzan la 'ala 'asās dīn aw nū' aw 'intimā' siyāsi aw fikri wa la bayn gani wa faqīr wa la bayn wazīr wa hafî̀ wa la bayn ra'īs wa mar'ūs. Citizenship does not classify people on any grounds like religion, gender, political or ideological interests, and wealth and poverty.

In 5, the negative predicates in the structures la 'a rif wațan li siwa mașr,I know no homeland other than Egypt and 'almuwāțana 'arḍ w 'ihlāṣ lil'aṛ̣ wa laysat dīn, citizenship is loyal belongingness to land not religion, are quite similar to the first two instances in 1 above.

We find an agreeable attitude towards Raheel that reflects that citizens of all religions are officially regarded equal in the following structures; 'ahlan wa sahlan bikī, you are welcome and iḥna niwașșal 'ilmuškila 'ila 'āli ra'îs mağlis 'alwzarā' 'almuhandis ibrāhīm mihlib, we will send it to the prime minister engineer Ibrahim Mihlib.

In 6, The negative predicate mathuṭ̂̄š in matḥuṭīs nafsik fi dayrit 'in kul ši' taṣnīf translated as don't get caught up in classifying everything, is used by one of Raheel's friends to advise her not be preoccupied with the idea of classifying.

To sum up, the ideologically based responses to Raheel's concept of citizenship in the preceding posts are all agreeable, harmonious and supportive. They have a clear positive attitude towards her. Raheel is regarded as an in-group member. For these reasons, these responses are placed in the white area.

\subsection{Group B}

\section{Passive responses}

In this group, responses are passive because the addressees do not give any reply to Raheel's messages to them. To reiterate, a context model refers to a communicative event involving some participants who exchange their ideologies, but in this particular case, only one participant, namely Raheel is willing to share her ideology with others.

Extracts 7-12 represent passive responses to Raheel's messages because none of the persons to whom her messages are sent responds. She tries to find out if every one of them is ready to accept the friendship of an Egyptian Jew who believes that citizenship equals faithful belonging to land, not religion. It strongly seems that the actor description of Raheel as a Jew is the crucial factor in having such passive reactions to Raheel's messages in spite of the fact that her words express her deep love of her country. These passive responses are placed in the grey area where there is no use of language at all and the attitudes of these persons towards Raheel are not clear and blurred. The grey area intersects the two other areas in figure 1 due to its indecisive nature. Probably, neglecting the response to a certain person is understood that he/she is not welcome. This may imply that these individuals regard Raheel as an out-group member and polarized as one of them not us.

\subsection{Group $C$}

\section{Negative responses}

The black area in the ideological spectrum includes negative responses which are conflicting with Raheel's concept of citizenship and co-existence. This ideological divergence is attributed to the different mental models of Raheel and other participants in this group. The mental models, shaped by personal experiences, of these individuals are most likely biased against Jews due to the long Arab-Israeli conflict. This explains the use of 
some harsh and offensive words as will be shown below. This signifies a tendency to exclude Egyptian Jews from the society which violates the concept of citizenship as stated in the Egyptian constitution.

13. rahîl zaki. 'ana yahudiya w mașriya ma ra'yak fi -lyahūd

wāw.mīm. 'alyahūd qawm ḍālīn w nag̣ḍ̄u (misprint) 'alayhim mit (misprint) allā ta' āla. 'inti qișitik 'ih w 'ih hịāyit 'il'as' ila

rahịil zaki. la ši' hada ra'yak w inta ḥur fih 'idan șadāqit 'ilfis laysa laha mubarrir l'an 'al'arā' lan tattafiq

wāw.mīm. 'ạ̣san

13. Raheel, "I am an Egyptian Jew. What do you think of Jews?"

W.M., "Jews are aberrant and detested by God."

"What is your story? Why do you ask these questions?"

Raheel, "Nothing at all. You are free to think that way. Then Facebook friendship is unjustifiable. We agree to disagree."

W.M., "It's better that way."

14. 'alif.'alif. ya hala nitšarraf biḥạ̣ritik

raḥil zaki. 'ana mașriya w 'a šaq turāb mașr wa lakinni yahudiya

'alif.'alif. min 'ayn bimașr bitta' kīd 'ilyahūd ya šaqūn turāb maṣr kama ya taqidūn 'annaha 'imtidād 'arḍuhum wa hāda min -lhurafăt

14. A.I., "Hello, Would you introduce yourself?"

Raheel, "I am Egyptian who adores the land of Egypt, but I am Jewish.”

A.I., "From which part of Egypt. Of course, Jews adore the land of Egypt as they believe that it is an extension of their land. This is falsehood."

15. bit ilmuhmil biyhrab 'abl bit ilzāalim ... 'ilkalām lilmașriyīn

'alif. mīm. 'in. 'inti miš mașriya

rahịil zaki. mașriya ğiddan w 'awza baladi 'ạ̣san balad w da hayḥ̣sal lamma -l'ihmāl 'illi fỉha bisabab -innās yintihi

'alif. ḥā'. țâlama 'inti mașriya 'izzay tu' ūli 'ilkalām lilmașriyīn

rahīl zaki. 'ilkalām lilmașriȳin ya ni lina kaša 'b mașri miš li'ay ša 'b tani

15. Raheel," The house of the negligent falls into ruin before that of the unjust. These words are for Egyptians."

A.M.A., "You are not Egyptian."

Raheel, "I am a very devoted Egyptian and want my country to be the best one. This will happen when negligence, done by its people, ends."

A.H.A., "If you are Egyptian, Why do you say that these words are for Egyptians?"

Raheel, "I mean us Egyptians not any other people."

16a. 'alif. yā'. ' antum 'alwabāāāā' wa ha'ulā’ ğaratīm Raheel Zaki

16 a. A. Y., "Raheel Zaki, you are an epidemic and they are germs."

16b. 'alif. yā'. w 'ala 'ih niḥibukum šufna 'ih minkum șạ mafǐs 'ahd līkum wa la 'amān wa la fi 'ulubkum raḥma Raheel Zaki taqtilūn -l'ațfāl w -nnisā' tata' āmarūn ḍid ğamī' ' adduwal w -l'āhir tu'ūli 'unșuriya hahaha

16b. A.Y., "Why would we love you? What have you done right? You are merciless and deceivers. You kill children and women and conspire against all countries. After all this you say racism hahahaha."

17a. dāl. mīm. ḥā', na am 'uhtā hunāk muslimīn w masihịīn ya malūn ğawāsīs wa lākin binisbit kam fi -lmi’a min -lmuslimīn 'aw -1 masihịīn wa nuqārin bayn hadihi -lnisba wa nisbithum fi -lyahūd linudrik -lfarq

17a. Dr.M.H., " Yes, sister, there have been Muslim and Christian traitors, but what is the ratio of these to Jew traitors? Let us draw a comparison to realize the difference."

17b. dāl. mīm. ḥā'. wa -tt ārīh 'ayḍan yaqūl'an -lfanāna rāqya 'ibrāhīm hāğarat 'ila -srā'īl wa 'amilat bi-lğayš

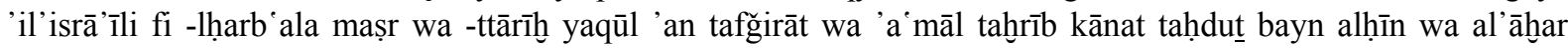
bi-madīnat 'al'iskandariya wa mudun mașr bi-'aydi -lyahūd wa yaqūl -ttārīh 'an -lyahūd -lmașriyīn kānu 'in 
'isrā'̄il ‘ala mașr fi -lhurūb 'ilmuhtalifa wa ḥata -l'ān

17b. Dr. M.H., “ History also mentions that the actress Raqia Ibrahim immigrated to Israel and joined the Israeli army against Egypt. Moreover, history states that explosions and acts of sabotage were committed by Jews in Alexandria and other Egyptian cities and that Jews have been Israel's eye on Egypt in different wars up till now."

18. F.A., "A Jewwwwwwwwwwwwwwwww. WTF (written in English)."

This acronym stands for 'What The Fuck'; an expression of disapproval and censure.

As for actor description, Raheel's description as a Jew is the main motive behind those participants' aggressive and intolerant attitude towards her in spite of her assertion that she is a loyal Egyptian citizen. In 16 a, A.Y describes Jews as an epidemic, which signifies his intense hatred of them.

Topics. The local semantics of the ideologically based responses to Raheel's ideas in this group mainly centre around displaying an extremely strong dislike of Jews in general in spite of the fact that Raheel's words always associate her with patriotic values. The global semantics or topics focus on citizenship.

Propositions. The predicates and arguments in this group mostly specify how Jews are evaluated by some Facebook users who seem to engage in a heated debate about whether Jews are good or evil with Raheel.

In 13, a person shows an aggressive attitude against Jews as stated in 'alyahūd qawm ḍālīn w nag̣̣ūb (misprint) 'alayhim mit (misprint) allā, which is translated as Jews are aberrant and detested by God. Raheel feels offended and uses the negative predicates laysa laha mubarrir which means that their Facebook friendship is not justifiable and lan tattafiq that refers to their opinions which will not mutually agree. The word 'ahsan meaning it's better that way is a common expression used when someone wishes to end a relation.

In 14, the person interacting with Raheel says wa hāda min -lhurafăt meaning this is falsehood to assert his rejection of the assumption that Egyptian Jews could be loyal citizens.

In 15, Raheel cites a well-known Egyptian proverb, but she is misunderstood because of the sentence that follows it, which makes others doubt her being an Egyptian. Thus someone says 'inti miš mașriya, you are not Egyptian and another one says țālama 'inti mașriya 'izzay tu'ūli 'ilkalām lilmașriyīn, if you are Egyptian, why do you say that these words are for Egyptians?. Her actor description represented by her name contributes to others' suspicion of her nationality and true intentions behind her words.

In 16, the response to Raheel is severe and hostile as obvious in the following structures:'antum 'alwabāāāā', you are an epidemic; mafǐš 'ahd līkum wa la 'amān wa la fi 'ulubkum rạ̣ma, you are merciless and deceivers and taqtilūn -l'ațfāl w -nnisā' tata' āmarūn ḍid ğamī' 'adduwal, You kill children and women and conspire against all countries. The use of the pronoun you repeatedly signifies that Jews are considered out-group members and polarized as them or more specifically you vs us.

In 17, Egyptian Jews are regarded as saboteurs as stated in 'an tafğirāt wa 'a māl tahrī̄ kānat taḥdut bayn alḥīn wa al'āhar bi-madīnat 'al'iskandariya wa mudun mașr bi-'aydi -lyahūd, explosions and acts of sabotage were committed by Jews in Alexandria and other Egyptian cities. The same person also describes them as spies as in wa yaqūl -ttārīh 'an -lyahūd -lmașriyīn kānu 'in 'isrā'īl 'ala mașr fi -lhurūb 'ilmuhtalifa wa hata -l'ān, history states that Jews have been Israel's eye on Egypt, i.e. spies in different wars up till now. Such fanatic and biased description of Jews mirrors a totally incompatible ideological attitude to Raheel's ideas of coexistence.

In 18, F.A. comments on Raheel's post on the wall of someone else who accepts her friendship request. In this post, Raheel thanks M.A for adding her and introduces herself as a loyal Egyptian Jew who believes that faithful citizenship is not confined to embracing a specific religion. M.A unfriended Raheel.

To sum up, participants in this group show a clear aggressive attitude to Raheel in spite of the fact that she does not use any inconvenient words or expressions. She is rejected mainly because of her religion as many people believe that the teachings of Judiasm call for abhorring and persecuting people embracing other religions. Furthermore, many people tend to exclude Egyptian Jews from the social scene because of the Arab-Israeli conflict and hold an extremist fanatic position that all Jews are enemies. This ascertains the fact that in many cases some people entirely refuse to accept or deal with those who are ideologically different. Polarization whose core idea is ideologically classifying Jews as Them versus $U_{s}$ is quite noticed. For all this, the ideologically based negative responses in this group are in the black area.

\section{Conclusion}

The current paper focuses on interpersonal ideological discourse and more specifically on proposing a spectrum by which ideologically based responses can be measured. As a result of some drastic political changes, the 
Egyptian society has witnessed during the last five years a wave of conflicting ideologies, each of which is endorsed by some people and rejected by others. The different types of social media such as Facebook and Twitter are global and influential channels of the communication of diverse ideologies. Facebook is used for data collection. One of the main findings reached through data analysis is the need for a device to measure responses to one's ideology. This facilitates classifying and understanding the different types of responses and their significance. Every area in the proposed ideological spectrum has a colour that is convenient to its nature; the colours are white, grey and black.

Language use in every group contributes to specifying the attitude of others to Raheel's ideology as either being positive or negative as in the first and third areas of the spectrum. Clarity of the attitude adopted is an aspect that relies to a great extent on language use. Thus, the positive and negative attitudes are clear enough like the clarity of the contrast between white and black. In the white area, ideologically-based responses are positive as shown in the use of supportive expressions like hada șahịḥ̣, this is true in 1; 'ağabni fikrit 'ittasāmuh 'illi bit abbari bīha fi ta 'liqātik, I like the idea of tolerance you express in your comments in 2; la lil' unșuriya wa na am lil' ihtilāf, no to racism, and yes to difference in 3; 'almuwāțana la ta 'rif tamyīzan la 'ala 'asās dīn aw nū' aw 'intimā' siyāsi aw fikri, citizenship does not admit discrimination in terms of religion, gender, political or ideological membership in 4, and 'ahlan wa sahlan bikī, you are welcome in 5 by the admins of the official page of the then prime minister.

By contrast, responses are racial and aggressive in the black area. Thus, one finds expressions that cast doubt on Raheel's nationality like 'inti miš mașriya, you are not Egyptian in 15. There are also harsh words such as 'antum 'alwabāāâ', you are an epidemic in 16; accusation that Jews are terrorists as in 'an tafğirāt wa 'a māl taḩrīb kānat taḥdut bayn alḥīn wa al'āḩar bi-madīnat 'al'iskandariya wa mudun mașr bi-'aydi -lyahūd, explosions and acts of sabotage were committed by Jews in Alexandria and other Egyptian cities in 17. In 18, someone says a Jewwwwwwwwwwwwwwwww. WTF an acronym stands for 'What The Fuck'; an expression of disapproval and censure. The grey area is different from the two other areas in that there is a complete absence of language use. In this confusing indecisive area, the attitude of others is unclear. This area intersects the two other areas because it is hard to ascertain that silence means the acceptance or rejection of Raheel's ideology.

Polarisation is an aspect that is closely related to one's attitude. In the white positive area, Raheel is treated as an in-group member and is polarized as one of $U s$. By contrast, in the black negative area, Raheel is regarded as an out-group member and as one of You vs $U s$ as quite evident in the use of the pronoun you in 16. In both cases, mental models, which are highly subjective, are responsible in many cases for judging others whether favourably or unfavourably. However, it is remarkable that negative judgments may be unjustifiable because Raheel's lexical choice reflects her loyalty and deep love of her country. There seems to be an unbridgeable divide between persons of different ideologies.Thus, in the negative area, Raheel is not welcome by some persons who, in principle, reject communicating with Jews even when they have the same nationality despite her lexical choice which should have made a favourable impression on others for being a decent and loyal citizen.

\section{References}

Androutsopoulos, J., \& Beißwenger, M. (2008). Introduction: Data and methods in computer-mediated discourse analysis.Language@Internet, 5, 1-7.

Kasaian, S., \& Tehrani, M. (2013). The Effect of Ideology on Lexical Choice. Journal of Academic and Applied Studies, 3, 22-35.

Kristiansen, G. (2001). Social and linguistic stereotyping: A cognitive approach to accents. Estudios Ingleses de la Universidad Complutense, 9, 129-145.

Simpson, P. (1993). Language, Ideology and Point of View. London: Routledge. https://doi.org/10.4324/9780203312612

Tuomela, R. (2007). The philosophy of sociality: The shared point of view. Oxford: University Press. https://doi.org/10.1093/acprof:oso/9780195313390.001.0001

Van Dijk, T. A. (1995a). Discourse semantics and ideology. Discourse \& Society, 6, 243-289. https://doi.org/10.1177/0957926595006002006

Van Dijk, T. A. (1995b). Discourse analysis and ideology analysis. In C. Schäffner \& A. Wenden (Eds.), Language and Peace (pp. 17-33). Aldershot: Dartmouth Publishing.

Van Dijk, T. A. (2001). Discourse, ideology and context. Folia Linguistica, 35(1-2), 11-40. https://doi.org/10.1515/flin.2001.35.1-2.11 
Van Dijk, T. A. (2013). Ideology and discourse. In M. Freeden, T. S. Lyman, \& M. Stears (Eds.), The Oxford Handbook of Political Ideologies (pp. 175-196). Oxford: Oxford University Press.

https://en.wikipedia.org/wiki/Hadith

https://en.wikipedia.org/wiki/_Language_ideology

http://www.statista.com/statistics/264810/number-of-monthly-active-facebook-users-worldwide/

http://www.wisegeek.com/what-is-language-ideology.htm

\section{Note}

Note 1. This is based on prophetic Hadith which refers to the record of words and actions of prophet Mohammed.

\section{Appendix A}

\section{Transliteration Table}

Transliteration symbols of Arabic letters.

, i

b ب

$\mathrm{t}$

$\underline{t} ث$

g ج

h $ح$

h $\dot{c}$

d $د$

d j

r J

z j

s w

ش ش

ص ص

ض ض

t b

ط

c $\varepsilon$

$\dot{\mathrm{g}} \dot{\varepsilon}$

f

q

k s

$1 \mathrm{~J}$

$\mathrm{m}$ ?

n ن

h。

w g

ي 


\section{Short Vowels}

a i u

\section{Long Vowels Compound Vowels}

$\bar{a} \bar{i} \mathrm{u}$ aw ai

The DIN 31635 standard for the transliteration of the Arabic alphabet is followed.

\section{Copyrights}

Copyright for this article is retained by the author, with first publication rights granted to the journal.

This is an open-access article distributed under the terms and conditions of the Creative Commons Attribution license (http://creativecommons.org/licenses/by/4.0/). 